\title{
THE ROLE OF THE HEAD OF MADRASAH'S POLICY IN IMPROVING TEACHER PROFESSIONALISM
}

\author{
Ahmad Nurulloh'), Andika Aprilianto' ${ }^{2)}$, Akhmad Sirojuddin ${ }^{3)}$, Muhammad Anas Ma arif ${ }^{3)}$ \\ ${ }^{1}$ Senior High School Tra Vinh, Vietnam \\ 2,3,4Fakultas Tarbiyah Institut Pesantren KH. Abdul Chalim Pacet Mojokerto Indonesia \\ nurulloh93@gmail.com, andika4ikhac@gmail.com, akhmadsirojuddin86@gmail.com, \\ Anasdt16@gmail.com,
}

\begin{abstract}
Abstrak
Penelitian ini bertujuan untuk mengetahui tentang peran kebijakan kepala madrasah dalam meningkatkan profesionalisme guru di MTs Unggulan Hikmatul Amanah. Metode penelitian yang digunkan adalab deskriptifkualitatif dengan menggunakan tektik pengumpulan data berupa observasi, dokumentasi dan wawacanra. Subjek penelitian ini yaitu kepala madrasah, waka keguruan dan guru-guru di MTs Unggulan Hikmatul Amanah. Hasil penelitian ini menunjukkean bahwa kebijakan kepala madrasah di MTs Unggulan Hikmatul Amanah cukup baik, dalam hal ini peran kebijakan kepala madrasah dalam rangka peningkatan profesionalisme guru sangat dominan. Kepala madrasah meimplementasikan kebijakan dengan cara mengadakan rapat bulanan; memberikan tugas; mengadakan diklat, seminar, workshop; memberikan reward/tunjangan kepada guru yang berprestasi dan sanksian kepada guru yang melanggar kebijakan di madrasah. Profesionalisme guru ditingkatkan dengan baik, terlibat pada: kedisiplinan keaktifan dalam pembelajaran; pengembangan keablian, dan mampu menguasai materi dalam pembelajran.
\end{abstract}

Kata Kunci: Kebijakan kepala Madrasah, Profesinalisme Guru, Madrasah Unggulan.

\section{Abstract}

This article aims to find out about the role of madrasa principals' policies in improving the professionalism of teachers at Madrasah Tsanawiyah (MTs) Unggulan Hikmatul Amanah. The research method used is descriptive-qualitative by using data collection techniques in the form of observation, documentation and discourse. The subjects of this study were the principal of the madrasa, teacher training staff and teachers at MTs Unggulan Hikmatul Amanah. The results of this study indicate that the policies of the head of the madrasa at MTs Unggulan Hikmatul Amanah are quite good, in this case the role of the principal's policies in order to increase teacher professionalism is very dominant. The principal of madrasa implements the policy by holding monthly meetings; giving assignments; holding training, seminars, workshops; provide rewards/allowances to teachers who excel and sanctions for teachers who violate policies in madrasah. Teacher professionalism is well improved, seen in: active discipline in learning; skill development, and being able to master the material in learning.

Keywords: Madrasa principal policy, Teacher Professionalism, Superior Madrasa.

\section{INTRODUCTION}

The principal of a madrasah is a teacher who gets additional assignments and is entrusted with being a madrasah or what in public schools is usually called the principal (Asyari, 2020; Krisbiyanto, 2019). The principal of a madrasah is someone who is given trust and has the responsibility of following a rule in education (Ekosiswoyo,
2016; Fauzi, 2017a). The head of madrasah has two functions, namely as an educator and as an educational staff. Despite getting additional assignments as head of the madrasah, the principal task of the madrasah head is the teacher who educates his students(Alam, 2018; Siahaan et al., 2020).

In the current era of globalization, there are various kinds of advances in the 
development of science and technology which are always growing rapidly every day. With this development it has an underlying influence on various political, economic, cultural and educational fields. That is what humans will face in this era, and this needs to get a solution from us as educators(Black \& Morrison, 2014; Daulay, 2014; Ramayulis, 2012).

The aim of education of the Indonesian nation has been described in the 1945 Constitution, Article 31, which states as follows "every citizen has the right to education". The constitutional foundation of this educational commitment is to provide the greatest possible opportunity for the Indonesian people to do good in the national education system by implementing policies in the field of government and development, including regional autonomy (Sirozi, 2005).

The above states that the fundamental thing in the center of society is madrasas. Therefore, the success or failure of a madrasah to provide satisfactory overall performance lies in the leadership qualities of the madrasah principal (Abd Hamid et al., 2012; Suwadi, 2017). Therefore, a madrasa principal has a leadership role which of course has a big influence in the environment for which he is responsible(Purwanto, 1987).
The most important thing in education is the need in society, the head of madrasah is expected to be able to provide innovative ideas that can produce policy alternatives to make an education system that is efficient, of quality and in accordance with the needs of society in various fields of life(Melanie C. Brooks \& Mutohar, 2018). The head of the madrasah is a leader who can recognize and understand various positions, conditions and all that is desired, which includes teachers and administrative staff and other assistants. Which later with the existence of good cooperation can produce harmonious thinking in efforts to improve madrasas(Mufidah, 2017; Zainuddin, 2014).

The principal of the madrasah is someone who plays a very important role as a person who becomes the captain, determines and moves the institution that is held by him, as a determinant of policy direction and always strives to improve and increase the effectiveness of performance in order to obtain satisfactory results (Cayamodin, 2019; Imam, 2018). The quantity possessed by a teacher is not the only determinant of the quality possessed by the madrasah. However, the leadership carried out by the head of the madrasah largely determines the quality of the madrasah. Engaging and empowering teachers should be done with respect and mutual respect and acknowledgment of each 
other's abilities(Setiyati, 2014; Somad \& Priansa, 2014).

Human resource management is one of the actions that can be taken by the principal of madrasah as a key and leader in madrasah which is a strategic way to improve the quality of education(Abdullah \& Syahri, 2019; Aydin, 2017). In terms of education, of course there are still many shortcomings that can result in the goals and plans that have been made and set previously not being achieved and running well. This is because management is still very low on human resources, education components, and the curriculum(Ariyanti et al., 2019).

And therefore, it is hoped that the principal of madrasah will always strive continuously as head of madrasah and also as a teacher in carrying out learning activities and improving the professionalism of teachers in madrasah. If the management is carried out properly, the existing potential is used as well as possible, it will produce quality educators.

MTs Unggulan Hikmatul Amanatul is a private educational institution under the auspices of the religious department, this madarasah is located $35 \mathrm{~km}$ from the capital of Mojokerto regency, to be precise in Bendungan Jati village, Pacet sub-district, Mojokerto regency which is located on an area of $5,700 \mathrm{~m} 2$. This institution was founded in 1999 and occupies the MIN Bendungan Jati building with afternoon lessons. In 2009, this institution received assistance from donors who then built a limited education building in stages.

In the implementation of the observations carried out at MTs Unggulan Hikmatul Amanah, the researcher saw some irregularities. One of them is the lack of role of the head of the madrasah as a leader in terms of empowering teachers' abilities / skills and the lack of attention of the head of madrasah to the welfare of teachers. Then the head of the madrasah is less able to manage human resources at the madrasah, resulting in teachers lacking professionalism in teaching at the madrasah, such as teachers arriving late, teachers not mastering learning material and teachers less able to socialize with students.

Based on the explanation above, the researcher is interested in conducting a study entitled: "The Role of Madrasab Principals in Improving Teacher Professionalism at MTs Unggulan Hikmatul Amanab".

\section{RESEARCH METHOD}

This article uses a qualitative research type with a descriptive approach. As for what is meant by qualitative data are analyzed inductively, results are more important than processes, humans are a research tool and so on (Creswell, 2007, 2012; Lexy J, 2011; Suharsimi, 2010). 
The subjects of this research were MTs Unggulan Hikmatul Amanah in Bendungan Jati Village, Pacet District, Mojokerto Regency, East Java Province from March 6, 2020 to March 19, 2020. The informants of this study were school principals, teachers, educational staff and teacher staff. Data collection techniques using observation, interviews and documentation. Meanwhile, the data analysis technique followed Hubberman's model, namely performing data reduction, data presentation and verification.

\section{RESULT AND DISCUSSION}

The policies that have been made and set by the principal of the madrasah are one of the keys that can determine the success of the madrasah in achieving its initial goals (Melanie Carol Brooks, 2017; Fauzi, 2017b). In making the policies to be implemented, the quality of the leaders in formulating these policies has a big influence on the success of the madrasah institutions, which are their work to achieve the goals(Ezzani \& Brooks, 2019). In this study discusses and provides an explanation of the role of policy in improving teacher professionalism at MTs Unggulan Hikmatul Amanah.

Related to this, the principal of MTs Unggulan Hikmatul Amanah said that (Zumar, personal communication, 2020):

"The process of determining the policy we already have a plan, our task as head of the madrasa cannot decide by ourselves, so we have to communicate and assist with teacher training. Then we determine policies for teachers who are less competent, then we hold coaching, training, workshops, or seminar. With the last order is education and training, we are participating in government education and training, namely from the training center. If our workshops can be held in our own environment, seminars are the same. But for education and training, the official education and training is training that is recognized by the government because it has a charter so that we participate but we cannot include everything. Starting from the teacher with subject $A$, then $B$ and so on until everyone gets a chance. Next, the potential can develop and run, so it must be financed, such as allowances. If the teacher gets sufficient allowances, sometimes the teacher can increase his or her own competency."

The interview with the head of the Madrasah is in line with the results of the interview with the Deputy Head of Teacher Training (Waka Keguruan, personal communication, 2020).

There are several items: The first is to assign assignments to the teacher in accordance with their main duties, for example, a biology teacher is given the task of teaching biology so that if a teacher does something according to his capacity, his professionalism will increase automatically and vice versa if the teacher is not given assignments according to their capacity, the professionalism of the teacher it will decrease. The second, is to increase the attendance rate, the teacher attendance here refers to the intensity of the meeting with students. When students often meet with their teachers, they become closer so that between the teacher and students it becomes easier 
to deliver learning. This has a good impact on teachers changing their selfdevelopment at a later date and students will easily gain knowledge. Third, increased teacher professionalism can be supported by allowances. As we know, the departure of a teacher to teach is for dedication, but the provision of policies from the head of the madrasah to teachers related to this service is changing rewards and so on. And the most important thing is communication, maintaining communication with the principal of the madrasah, stakeholders and all school elements. Because each individual has a different view, maybe for us it is wrong, but for others it is not necessarily wrong, there is a need for communication. Because with communication, problems will find common ground. If there is an error, it can be corrected and if there is a deficiency it can be improved."

Whereas Kleint and Murphy argue that a policy is "a set of goals, principles and rules that guide an organization, policies thus cover the entire organization's guidelines(Syafaruddin, 2002)".

It can be understood based on the results of the interview that there are several policies from the principal of madrasah to improve professionalism and are in line with (E Mulyasa, 2011; Udin, 2013):

Organizing workshops, training, seminars and so on to increase teacher knowledge, (2) assignments given to teachers are tailored to their education, (3) ) provide rewards or goals if the teacher achieves, (4) increases the discipline of the teacher with his presence, (5) the principal communicates with the teachers and all elements of the madrasah.

The principal's policy is a form of action that responds to problems that have arisen or anticipates problems that will arise at a later date. The policies that have been created and established are to achieve the desired goals. In terms of establishing policies, the principal of madrasah said that:

"The process of determining the policy we already have a plan, our task as head of madrasah cannot decide on our own, so we have to communicate and assist with teacher time. Then we determine policies for teachers who are lacking in competence, then we hold coaching, training, workshops, or seminar" (Zumar, personal communication, 2020).

The determination of madrasah principal policies related to the profession of miscarriage needs consideration from teacher training. Because in this case the teacher training time has a function as monitoring the performance of the teacher. Teacher training in relation to policy making also reveals that (Waka Keguruan, personal communication, 2020):

"There are 2 lines we use here. The first is the bottom-up system, where we learn how the teacher is at the bottom, then there will be attitude and decision making. The second is up-to-down, or from top to bottom. There are 2 directions, the first is from the government in this case the Ministry of Religion, the second is the policy of the head of the foundation. Where these 2 lines adhere to the vision and mission of the institution. If there is one 
example from the government, for example there is a circular, there are regulations relating to laws which are then narrowed back to a foundation decree, and reduced to a decision letter of the head of the madrasa to issue policies. For the bottom-up study, what is the turmoil with regard to students, teachers and others, so it is necessary to have a separate policy that was spelled out in a madrasah decree which will later be accountable to superiors, namely the head of the foundation. "

This is supported by the statement of one of the teachers at MTs who stated that policies are not solely decided by the head of the madrasah but are assisted and communicated with several parties so that the decisions taken can produce mutual benefit. In an interview with a Fiqh teacher, he said that:

"The principal of the madrasa may
often conduct meetings and
communications to determine
something and delegate back to his
representatives in making decisions."
When it comes to establishing policies,
it needs coordination and consolidation
so that it is not a policy that is decided
by one party. Here the head of the
madrasa considers which maslahah and
disadvantage is greater so that yesterday
we had a meeting to consider and
determine what it would be like, the
head of the madrasah must hold a
meeting and coordinate in determining
policies(S. Q Qulub,
communication, 2020)"

So, in determining policies at MTs Hikmatul Amanah, the head of the madrasah responds to important conditions or problems relating to teachers by emphasizing communication.

Based on the results of the interviews that have been presented, the conclusions that can be drawn are in determining something that has a relationship with policy, the principal of the madrasah with teachers and staff conducts a meeting first regarding madrasah policies, teacher professionalism in MTs Unggulan Hikmatul Amanah is increased or developed by including teachers -the teacher in seminars and training and training in accordance with the policies of the head of the madrasa.

With the professionalism of madrasah principals, increasing teacher professionalism is easy to implement because the madrasah principal understands his role and function, understands the teacher's needs in carrying out the learning process or the existing rules in the institution(Fitriani, 2017; Raihani, 2017). This is because as a teacher not only must be able to understand and master the material to be taught to students, not only provide and teach students about science, but can provide motivation to students, have high insight and skills.

In the interview, the authors saw several responses from teachers regarding the policies of the principal at MTs Unggulan Hikmatul Amanah that "Of the 
70 s teachers the response was not 100\% good, this is natural when someone does not understand the policies of the madrasa principal but overall I can say that $98 \%$ is supportive".

Indeed, it cannot be $100 \%$ maximum because there are still some homework that have not been completed, such as students wandering around when learning hours are the task of the teacher who must condition them. If I want the principal of the madrasa to be firm, but because the teacher is also a human, sometimes he or she experiences aging such as illness, being unable to do so or other things, so indeed this cannot be forced, but everything has gone well, such as when the teacher is unable to attend, he can leave the material or assignment to the picket teacher. From a planning point of view it is good but from the implementation it is still an obstacle.

The results obtained from the interview can provide an answer that the role of the head of madrasah in improving teacher professionalism through the steps implemented is quite good.

Competence as a learning agent for elementary and junior high school and early childhood includes: social competence, pedagogic potential, professional competence and personal competence. This is in accordance with government regulations regarding National Education Standards in article 28 paragraph 3, 2005 No. 19.

In the national development of education, the position, role and function of teachers are very important and strategic. It is very necessary for professional educators or teachers to achieve the goals of National Education, develop whole people and educate the life of the nation.

In the interview the head of the Madrasah emphasized that:

"The state of teacher competence here varies. There are those whose competencies are already good, in the sense that they are in accordance with the subjects they hold when teaching. On average, we think the competence is good, but in practice some of them are lacking and some are more. For example, let's say from this teacher, for example, the Indonesian language between the subject and the academic department is appropriate, but the way of applying it to students and so on varies and varies so that automatically the advantages and disadvantages are still there. That is the state of the competence of each teacher(Zumar, personal communication, 2020).

This was confirmed by the teacher representative, he said in the interview that:

"We have 76 teachers, all of whom are in accordance with their competencies. We have 14 teachers who are already professionals or in other words are professional, which is proven by the existence of certification. We also have 6 impassing teachers, then some of the existing teachers are all in accordance with their educational qualifications but 
there are local content subjects such as Javanese for which we have not found teachers who match their diplomas. For the others it is in accordance with the composition.(Waka Keguruan, personal communication, 2020) "

From the interview above with the head of madrasah and teacher training, it can be concluded that the potential of teachers at MTs Unggal Hikmatul Amanah varies and to improve teacher competence, the head of madarsah conducts coaching, such as workshops, training and through coaching that has a linkage like supervisors. And 76 teachers who are all in accordance with their competencies. Madrasahs have 14 teachers who are already professions or in other words are professionals, which is proven by the existence of certification.

Dr. Moh. Ali, Udin and Mulyasa also argued that a teacher must have special requirements, namely: 1) From the work he does, there is a sense of sensitivity to the social impacts. 2) Expertise is more emphasized in certain fields according to their profession. 3) Skills based on the concept of qualified scientific theory. 4) Having an adequate level of teacher training. 5) Having sensitivity to the social impact of the task to be carried out(E Mulyasa, 2011; Udin, 2013; Usman, 1999).

In this regard, to improve teacher professionalism, the head of madrasah added in his statement that:
"If there is a result of each teacher's competence that is still lacking, sufficient or more, then we are the ones monitoring the teachers so that we can sort out which group of teachers, so there are classifications $\mathrm{A}, \mathrm{B}, \mathrm{C}$. the $\mathrm{B}$ and $\mathrm{C}$ we need to improve and also need guidance (Zumar, personal communication, 2020)"

In an interview with a Fiqh teacher

(S. Qulub, personal communication, 2020), he explained that:

"The first is he held a meeting for evaluation. Secondly, he usually coordinates with teacher teachers to ask how the teacher is, whether anyone is absent or if there are things that make teaching and learning activities delayed. Besides that, the principal is usually a supporter, the support here means a lot, the first is welfare, because we are here implementing a full-day school. Say 8 or up to 9 hours the teacher teaches, so we need nutrition, so the principal has a policy to meet needs such as food, drink, food and so on. And the principal of madrasah also holds training and seminars to improve teacher professionalism or (MGMP) Subject Teacher Conference."

Besides that, teachers Muadalah and Aswaja also added in this regard in the interview that:

"The principal of the madrasah provided the opportunity to increase my potential by continuing my education to a higher level. I was able to continue studying at IKHAC thanks to his approval. "

Therefore, it can be concluded that the competence of teachers is developed or enhanced by the head of madrasah in some of the policies under his supervision other than the principal of holding training or 
seminars to improve teacher professionalism, how is the role of the principal in providing opportunities and opportunities for teachers to continue their studies, providing rewards or allowances for teachers who excel in teaching (Bustamar et al., 2016; Hamzah B, 2011; Syam, 2016). In addition, the teachers at MTs Unggulan Hikmatul Amanah also share knowledge with their colleagues.

The teacher is a profession that has a professional duty or professional position as the interests of the profession and is also an expert specifically who is an expert in learning. Based on this, the behavior of a teacher is as follows: (1) Legislation, (2) Professional Organizations, (3) Peers, (4) Students, (5) Workplace, (6) Leaders, and (7) Work (Kosasi, 2004; Mu'ammaroh, 2016; Ramayulis, 2013).

The principal of madrasah must have the intelligence and managerial ability, which is good ideas for the advancement of madrasah (Fatoni, 2017). Can organize all the stuf to carry out the program that has been set for the annual work plan, which is able to provide motivation by all academic staff and non-academic staff, and also respect all staff (Ma`arif, 2017) (Solikatun, 2019). The madrasah principal must be able to communicate well with all his staff in order to understand what they are going to do, and be able to motivate them to work well in advancing the madrasah institution(Asmiyati, 2018). And the principal of madrasah must be able to objectively evaluate all the tasks that have been completed by his work team, and can be an inspiration for evaluation in the future(Jiayi \& Ling, 2012; Mahfud, 2019).

In this regard, (Muhibbin Syah, 2013) explained that a teacher must have ten basic competencies, namely: 1) A teacher must be able to master the material / material to be taught. 2) Can organize and process teaching and learning programs. 3) Reliable in class management. 4) In the learning process using media or teaching materials. 5) Mastering the foundation of education. 6) Good at processing teaching and learning interactions. 7) Assessing student achievement for teaching purposes. 8) Get to know the guidance and counseling program at madrasah. 9) Know and organize madrasa administration. 10) Understand the principles and interpret the results of educational research for teaching purposes.

Related to this, in interviews with teachers at MTs Unggulan Hikmatul Amanah as follows, such as teachers Muadalab and Aswaja said that:

"I feel there is no problem in mastering the material because Aswaja material, for example, has often been discussed on various occasions, both recitation and information events in the community and students have often 
repeated the material, besides that the material for class VII and other classes is the same so it has been repeated. repeatedly taught by the mother even memorized.(Mafula, communication, 2020)"

personal

The head of the madrasa also

confirmed about this that:

"More specifically, we start, if we increase the potential in the discipline category, the teacher must be diligent in entering. Because of what, even smart teachers rarely enter, it's useless. So activeness first, discipline comes first, then our potential is involved in it. So first personal competence. And other competencies will follow, such as social, pedagogic, professional. "

The conclusion from the interviews described above is that madrasah principals improve teacher professionalism through fostering teacher personal competence, especially teacher activity in madrasah activities. If the personal competence of the teacher is good, then other competencies will also follow. Teachers in madrasah can master the material and manage classes. Looking at the data from above shows that the professionalism of teachers at MTs Unggulan Hikmatul Amanah is also quite good.

\section{CONCLUSSION}

The role of the principal's policies in improving the professionalism of teachers at MTs Unggulan Hikmatul Amanah is based on the data collected and the results of good cupkup analysis. The policy of the principal of madrasah in improving teacher professionalism at MTs Unggulan Hikmatul Amanah is quite good. To develop teacher professional competence, the head of madrasah does this through coaching seminars, training, workshops or so on. Communicating with teachers well, motivating teachers, giving rewards or allowances to teachers who excel in teaching. Hold a meeting with teachers every month for evaluation. And the professionalism of teachers at MTs Unggulan Hikmatul Amanah is also quite good. The teacher is given a reward if the teacher achieves and is given a penalty if the teacher is not professional in teaching. Teacher personal competence is prioritized through the discipline of teacher activity in madrasah activities. Teachers at MTs Unggulan Hikmatul Amanah are relatively able to master the material and manage the class well.

\section{REFERENCES}

Abd Hamid, S. R., Syed Hassan, S., \& Ismail, N. A. (2012). Teaching Quality and Performance Among Experienced Teachers in Malaysia. Australian Journal of Teacher Education, 37(11). https://doi.org/10.14221/ajte.2012v37 $\mathrm{n} 11.2$

Abdullah, M. L., \& Syahri, A. (2019). Model of Religious Culture Education and Humanity. Nadwa, 12(2), 331-344. https://doi.org/10.21580/nw.2018.12.2 .2756

Alam, N. A. R. (2018). Strengthening Leadership Culture (The Role of Kyai in 
Indonesian Pesantren). At-Ta'dib, 13(1), undefined-undefined.

https://doi.org/10.21111/at-

tadib.v13i1.1986

Ariyanti, N. S., Supriyanto, A., \& Timan, A. (2019). Kontribusi Kepala Sekolah Berdasarkan Ketidaksesuain Kualifikasi Guru Untuk Meningkatkan Kualitas Sekolah. Nidhomul Haq: Jurnal Manajemen Pendidikan Islam, 4(2), 157168.

https://doi.org/10.31538/ndh.v4i2.314

Asmiyati, A. (2018). Model Kepemimpinan Kepala Madrasah dalam Meningkatkan Mutu Sumber Daya di Madrasah Ibtidaiyah Ma'arif Giriliyo I Wukirsari Imogiri Bantul. Jurnal Pendidikan Madrasah, $\quad 3(1), \quad$ 41-54. https://doi.org/10.14421/jpm.2018.3104

Asyari, S. (2020). Supervisi Kepala Madrasah Berbasis Penilaian Kinerja sebagai Upaya Peningkatan Profesionalitas Guru. JIEMAN: Journal of Islamic Educational Management, 1(2), 149-163. https://doi.org/10.35719/jieman.v1i2.1 4

Aydin, N. (2017). Spirituality and subjective wellbeing: Living a fulfilled life without falling into the trap of consumer culture. Humanomics, 33(3), 300-314. https://doi.org/10.1108/H-03-20170052

Black, J. S., \& Morrison, A. J. (2014). The Character of Global Leaders. In Advances in Global Leadership (Vol. 8, pp. 183-204). Emerald Group Publishing Limited.

https://doi.org/10.1108/S1535120320140000008016

Brooks, Melanie C., \& Mutohar, A. (2018). Islamic school leadership: A conceptual framework. Journal of Educational Administration and History, 50(2), 54-68. https://doi.org/10.1080/00220620.201 8.1426558
Brooks, Melanie Carol. (2017). Southern Filipino school leaders and religious diversity: A typology. International Journal of Educational Management, 31(5), 646-660. https://doi.org/10.1108/IJEM-082016-0164

Bustamar, Idris, J., \& Khairuddin. (2016). Strategi Kepala Sekolah Dalam Pengembangan Profesional Tenaga Kependidikan Pada Sma Negeri 5 Darussalam Banda Aceh. Jurnal Administrasi Pendidikan: Program Pascasarjana Unsyiah, 4(1). http://www.jurnal.unsyiah.ac.id/JAP/a rticle/view/2603

Cayamodin, J. R. (2019). The Prospect of Integrated and Holistic Madrasah Education System (ihmes) in the Philippines: A Sustainable Approach to Prevent Violent Extremism. TARBIYA: Journal of Education in Muslim Society, 6(1), 88-102.

https://doi.org/10.15408/tjems.v6i1.11 628

Creswell, J. W. (2007). Qualitative inquiry \& research design: Choosing among five approaches (2nd ed). Sage Publications.

Creswell, J. W. (2012). Educational research: Planning, conducting, and evaluating quantitative and qualitative research (4th ed). Pearson.

Daulay, H. P. (2014). Pendidikan Islam dalam Perspektif Filsafat. Kencana Prenada Media Group.

E Mulyasa. (2011). Menjagi Guru Profesional Menciptakan Pembelajaran Kreatif dan Menyenangkan (11th ed.). Rosdakarya.

Ekosiswoyo, R. (2016). Kepemimpinan kepala sekolah yang efektif kunci pencapaian kualitas pendidikan. Jurnal Ilmu Pendidikan, 14(2).

Ezzani, M., \& Brooks, M. (2019). Culturally Relevant Leadership: Advancing Critical Consciousness in American Muslim Students. Educational Administration Quarterly, $\quad$ 55(5), 781-811. 
https://doi.org/10.1177/0013161X188 21358

Fatoni, M. (2017). Peran Kepala Madrasah Dalam Meningkatkan Mutu Guru Di Mts Nurul Falah Talok Kresek Kabupaten Tangerang. Tarbawi: Jurnal Keilmuan Manajemen Pendidikan, 3(02), 168-182.

https://doi.org/10.32678/tarbawi.v3i02 .1787

Fauzi, A. (2017a). Kepemimpinan Kepala Madrasah Dalam Mengembangkan Lembaga Pendidikan Islam. Nidhomul Haq: Jurnal Manajemen Pendidikan Islam, 2(2), 42-53. http://ejournal.ikhac.ac.id/index.php/nidhomul haq/article/view/31

Fauzi, A. (2017b). Kepemimpinan Kepala Madrasah Dalam Mengembangkan Lembaga Pendidikan Islam. Nidhomul Haq: Jurnal Manajemen Pendidikan Islam, 2(2), 42-53. http://ejournal.ikhac.ac.id/index.php/nidhomul haq/article/view/31

Fitriani, M. I. (2017). Systemic and Systematic Steps of Leadership on Transforming Symbolic into Substantive Characteristic of Madrasah. Jurnal Pendidikan Islam, 3(1), 1-16. https://doi.org/10.15575/jpi.v3i1.1203

Hamzah B, U. (2011). Profesi Kependidikan, Problema, Solusi dan Reformasi di Indonesia. Bumi Aksara.

Imam, M. (2018). The Handbook of Education Management: Teori dan Praktik Pengelolaan Sekolah/Madrasab di Indonesia Edisi 2. Prenada Media.

Jiayi, W., \& Ling, C. (2012). Reviewing Teacher Evaluation of Rewards and Punishments: The Overview of Chinese Teacher Evaluation Research. Education Research International, 2012, 1-16. https://doi.org/10.1155/2012/184640

Kosasi, S. dan R. (2004). Profesi Keguruan. Rineka Cipta.

Krisbiyanto, A. (2019). Efektifitas Kepemimpinan Kepala Madrasah terhadap Mutu Pendidikan MTsN 2 Mojokerto. Nidhomul Haq: Jurnal Manajemen Pendidikan Islam, 4(1), 52-69. https://doi.org/10.31538/ndh.v4i1.182

Lexy J, M. (2011). Metodologi penelitian Kualitatif (29th ed.). Rosdakarya.

Ma`arif, M. A. (2017). Analisis Konsep Kompetensi Kepribadian Guru PAI menurut Az-Zarnuji. ISTAWA, 2(2), 35-60.

Mafula. (2020). Guru Muadalah dan Aswaja Tsanawiyah Hikmanatul Amanah Bendungan Jati Mojokerto [Personal communication].

Mahfud, C. (2019). Evaluation of Islamic Education Curriculum Policy in Indonesia. Premiere Educandum: Jurnal Pendidikan Dasar Dan Pembelajaran, 9(1), 34-43.

Mu'ammaroh, N. lail R. (2016). Antara Profesi, Kompetensi Dan Tugas Kependidikan Seorang Guru. Madrasah, 7(1), 18. https://doi.org/10.18860/jt.v7i1.3305

Mufidah, N. (2017). Peran Manajer Kepala MIN Jejeran Bantul dalam Implementasi Manajemen Berbasis Madrasah. MANAGERIA: Jurnal Manajemen Pendidikan Islam, 2(1), 45-62. https://doi.org/10.14421/manageria.20 17.21 .03

Muhibbin Syah. (2013). Psikologi Pendidikan dengan pendekatan baru (18th ed.). Remaja Rosdakarya.

Purwanto, M. N. (1987). Administrasi dan supervisi pendidikan. Remadja Karya.

Qulub, S. (2020). Guru Fiqih Madrasah Tsanawiyah Hikmanatul Amanah Bendungan Jati Mojokerto [Personal communication].

Raihani, R. (2017). Exploring Islamic School Leadership in a Challenging Southern Thailand Context. Studia Islamika, 24(2), 271-293. https://doi.org/10.15408/sdi.v24i2.460 8

Ramayulis. (2012). Sejarah Pendidikan Islam, Napaktilas Perubahan Konsep, Filsafat dan Metodelogi Pendidikan Islam dari Era Nabi 
Saw sampai Ulama' Nusantara. Kalam Mulia.

Ramayulis. (2013). Profesi dan Etika Keguruan. Kalam Mulia.

Setiyati, S. (2014). Pengaruh kepemimpinan kepala sekolah, motivasi Kerja, dan budaya sekolah terhadap kinerja guru. Jurnal Pendidikan Teknologi Dan Kejuruan, 22(2), 200-206.

Siahaan, A., Rafida, T., \& Batubara, K. (2020). Influence of Madrasah Head Leadership, Motivation and Madrasah Culture on Teacher Performance in Madrasah Aliyah Model 2 Medan. Budapest International Research and Critics Institute (BIRCI-Journal): Humanities and Social Sciences, 3, 2174-2182. https://doi.org/10.33258/birci.v3i3.11 50

Sirozi, M. (2005). Politik pendidikan: Dinamika bubungan antara kepentingan kekuasaan dan praktik penyelenggaraan pendidikan. RajaGrafindo Persada.

Solikatun, U. H. (2019). Korelasi Gaya Kepemimpinan Kepala Madrasah Dan Motivasi Kerja Guru Terhadap Kinerja Guru Di Madrasah Aliyah Negeri 3 Nganjuk.

Somad, D. J., \& Priansa, D. J. (2014). Manajemen Supervisi dan kepemimpinan kepala sekolah. Bandung: Alfabeta.

Suharsimi, A. (2010). Prosedur Penelitian, Suatu Pendekatan Teori dan Praktek (14th ed.). Rineka Cipta.

Suwadi, S. (2017). Educational Leadership Based on Social Capital for Improving Quality of Private Secondary School. Jurnal Pendidikan Islam, 6(2), 449. https://doi.org/10.14421/jpi.2017.62.4 $49-478$

Syafaruddin. (2002). Manajemen mutu terpadu dalam pendidikan: Konsep, strategi, dan aplikasi. Gramedia Widiasarana Indonesia.

Syam, M. N. (2016). Menegakkan Kode Etika Profesi Guru dalam Rangka Meningkatkan Citra Profesi Guru dan Jiwa Korps Keguruan: Wawasan dan
Pengalaman Filsafat Pendidikan. Jurnal Ilmu Pendidikan, 6(3). https://doi.org/10.17977/jip.v6i3.2334

Udin, S. S. (2013). Pengembangan Profesi Guru (Cet. 3). Alfabeta.

Usman, M. U. (1999). Menjadi guru profesional. Remaja Rosdakarya.

Waka Keguruan. (2020). Wakil Kepala Madrasah Bidang Keguruan Tsanawiyah Hikmanatul Amanah Bendungan Jati Mojokerto [Personal communication].

Zainuddin, M. R. (2014). Manajemen Kepala Madrasah Dalam Pengembangan Profesionalisme Guru Pendidikan Agama Islam (pai). Edukasi: Jurnal Pendidikan Islam, 2(2), 632-644. https://doi.org/10.5281/ejournal.v2i2.166

Zumar. (2020). Kepala Madrasah Tsanawiyah Hikmanatul Amanah Bendungan Jati Mojokerto [Personal communication]. 